\title{
Isolation and Characterization of Microsphaera multipartita gen. nov., sp. nov., a Polysaccharide-Accumulating Gram-Positive Bacterium from Activated Sludge
}

\author{
YUKIHIKO YOSHIMI, ${ }^{1}$ AKIRA HIRAISHI, ${ }^{2}$ AND KAZUNORI NAKAMURA ${ }^{3 *}$ \\ Tsukuba Laboratory, Taki Chemical Co., Ltd., 2-1-6 Sengen, Tsukuba, Ibaraki 305, ${ }^{1}$ National Institute of Bioscience \\ and Human-Technology, Agency of Industrial Science and Technology, 1-1 Tsukuba, Ibaraki $305,{ }^{3}$ and Laboratory \\ of Environmental Biotechnology, Konishi Co., Ltd., 5-6-3 Yokokawa, Sumida-ku, Tokyo 130, ${ }^{2}$ Japan
}

\begin{abstract}
A new gram-positive bacterium was isolated from activated sludge acclimated with sugar-containing synthetic wastewater. This organism, designated strain $\mathrm{Y}-104^{\mathrm{T}}(\mathrm{T}=$ type strain), was a coccus-shaped, aerobic chemoorganotroph that had a strictly respiratory type of metabolism with oxygen as the terminal electron acceptor. This strain accumulates large amounts of polysaccharide in its cells. Strain $\mathrm{Y}-104^{\mathrm{T}}$ has the following chemotaxonomic characteristics: it contains menaquinone MK-8 $\left(\mathrm{H}_{4}\right)$, its DNA G+C content is $67.5 \mathrm{~mol} \%$, and it contains meso-diaminopimelic acid. No previously described high-G+C-content gram-positive coccus contains both MK-8 $\left(\mathrm{H}_{4}\right)$ as a major quinone and meso-diaminopimelic acid in its cell wall. A phylogenetic analysis based on 16S rRNA sequences showed that strain $\mathrm{Y}-104^{\mathrm{T}}$ represents a line of descent distinct from those of previously described species of high-G+C-content gram-positive bacteria and that members of the genus Frankia are the nearest neighbors. Therefore, we concluded that our isolate should be assigned to a new genus and species, for which we propose the name Microsphaera multipartita. The type strain is strain Y-104.
\end{abstract}

Activated sludge is a rich source of aerobic chemoorganotrophic bacteria which belong to various taxonomic and phylogenetic groups, and some of these organisms may not have been described yet. The community structure of activated sludge systems varies remarkably in response to the chemical nature of the wastewater and the operational conditions, and bacteria capable of rapid uptake and accumulation of substrates from the wastewater may predominate under substrate-limiting conditions, particularly when substrate addition is intermittent (for example, in batch treatment processes). The fact that activated sludges contain large amounts of reserve materials, such as glycogen, polyhydroxyalkanoates, and polyphosphate, under certain conditions suggests that there are bacterial species that have the ability to accumulate these reserve materials. Our recent study demonstrated that a new polyphosphateaccumulating gram-positive bacterium (22), for which we proposed the name Microlunatus phosphovorus (21), is present in activated sludge showing enhanced phosphate removal.

The bacterial composition and capacity for polysaccharide accumulation of activated sludge treating carbohydrate-containing wastewater have been major subjects of study (27-30, $34)$. Early reports in the literature showed that large coccusshaped gram-positive bacteria constituted significant proportions of the bacterial flora of activated sludge loaded with carbohydrate-rich wastewater $(28,30)$, although no detailed taxonomic study of these gram-positive cocci was performed thereafter. Activated sludge cultured under batch operational conditions with intermittent addition of substrate containing glucose showed rapid substrate uptake and accumulated substrate as polysaccharide which was later consumed slowly for the synthesis of DNA, RNA, and protein (20). Accordingly, to elucidate the mechanism of selection of bacteria in activated sludge processes, we focused on the capacity for substrate uptake and accumulation of bacteria that predominate in activated sludge acclimated with sugar wastewater. During this study, we found that large coccus-shaped bacteria containing

\footnotetext{
* Corresponding author.
}

tetrahydrogenated menaquinones with eight isoprene units $\left[\mathrm{MK}-8\left(\mathrm{H}_{4}\right)\right]$ predominated in the sludge, as estimated by microscopic observations and a direct quinone profile analysis of this sludge. Our attempt to isolate large gram-positive cocci that contain MK- $8\left(\mathrm{H}_{4}\right)$ from the sludge was successful. The isolates which we obtained, which were found to accumulate large amounts of polysaccharides within their cells, were morphologically similar to members of the recently created genera Luteococcus (33) and Microlunatus (21), but differed from these taxa in basic taxonomic characteristics. In this report we describe the isolation and phenotypic and phylogenetic characterization of one of the new isolates, and we propose that this isolate should be placed in a new genus and species, for which we propose the name Microsphaera multipartita.

\section{MATERIALS AND METHODS}

Isolation and cultivation. Activated sludge was cultured aerobically in a fedbatch reactor system (length of cycle, $8 \mathrm{~h}$ ) with synthetic wastewater containing (per liter) $0.75 \mathrm{~g}$ of glucose, $0.03 \mathrm{~g}$ of peptone, $0.03 \mathrm{~g}$ of yeast extract, $0.1 \mathrm{~g}$ of $\left(\mathrm{NH}_{4}\right)_{2} \mathrm{SO}_{4}$, and $0.07 \mathrm{~g}$ of $\mathrm{KH}_{2} \mathrm{PO}_{4}$. At the end of each batch cycle, the sludge was sedimented, and two-thirds of the supernatant was replaced with the same volume of the synthetic medium. After 90 days of acclimation, bacteria were isolated from the sludge by the dilution plate method with GPY agar, which contained (per liter) $1.0 \mathrm{~g}$ of glucose, $0.5 \mathrm{~g}$ of peptone, $0.5 \mathrm{~g}$ of yeast extract, 0.1 $\mathrm{g}$ of $\mathrm{KH}_{2} \mathrm{PO}_{4}, 0.1 \mathrm{~g}$ of $\left(\mathrm{NH}_{4}\right)_{2} \mathrm{SO}_{4}$, and $0.1 \mathrm{~g}$ of $\mathrm{MgSO}_{4} \cdot 7 \mathrm{H}_{2} \mathrm{O}(\mathrm{pH} 7.0)$. The plates were incubated at $25^{\circ} \mathrm{C}$ for 20 days. Colonies appearing on the plates were picked for standard purification. In this procedure we paid special attention to the slowly growing colonies which appeared after 10 days of incubation. Isolates were maintained on GPY agar slants and were subcultured every month. For routine phenotypic tests, cells were grown aerobically at $25^{\circ} \mathrm{C}$ in GPY medium.

Morphological characteristics. Gram staining was performed with a FAVOR. G SET·F kit (Nissui Pharmaceutical Co., Ltd., Tokyo, Japan). Cell morphology was examined by phase-contrast microscopy, scanning electron microscopy, and transmission electron microscopy. For scanning electron microscopy, cultured cells were harvested by centrifugation, washed, and suspended in $20 \mathrm{mM}$ phosphate buffer ( $\mathrm{pH} 7.0$ ). The suspended cells were fixed with $5 \%$ glutaraldehyde and postfixed with $1 \%$ osmium tetroxide. The fixed cells were dehydrated through a graded ethanol series, and the ethanol was replaced with isoamyl acetate. After critical point drying, the samples were sputter coated with gold and observed with a model JSM-840AP scanning electron microscope (JEOL, Ltd., Tokyo, Japan). For transmission electron microscopy, centrifuged cells were fixed with $5 \%$ glutaraldehyde and postfixed with $1 \%$ osmium tetroxide. The fixed cells were stained with $2 \%$ uranyl acetate, dehydrated through a graded ethanol series, and embedded in an epoxy resin. Ultrathin sections of samples were prepared with an 
ultramicrotome and examined with a model $\mathrm{H}-7000$ transmission electron microscope (Hitachi, Ltd., Tokyo, Japan).

Sugar uptake measurement. Cells were harvested from cultures at the stationary phase, washed with distilled water, and then resuspended in distilled water at a concentration of $1.0 \mathrm{~g}$ (dry weight) of cells per liter. Either glucose, fructose, mannose, galactose, xylose, maltose, sucrose, lactose, or melibiose was added to the suspended cells as a substrate to a concentration of $1.0 \mathrm{~g} /$ /iter under aerated conditions, which were maintained by using a glass diffuser and an aeration rate of 0.5 volume/volume/min. The $\mathrm{pH}$ was kept at 7.0 by using a $\mathrm{pH}$ controller. Sugar uptake was evaluated by monitoring the decrease in the sugar concentration in the liquid phase. The sugar concentration was determined colorimetrically by the phenol-sulfate method (6). Whole-cell polysaccharide content was also estimated by using the phenol-sulfate method after washing with distilled water.

Physiological and biochemical characterization. Oxidase activity was determined by monitoring the oxidation of tetramethyl-p-phenylenediamine on filter paper. Catalase activity was determined with a $3 \%$ hydrogen peroxide solution. The media used to evaluate utilization of various substrates for growth were prepared by adding $1.8 \mathrm{~g}$ of each substrate to a basal medium ( $\mathrm{pH} 7.0$ ) containing (per liter) $0.1 \mathrm{~g}$ of peptone, $0.1 \mathrm{~g}$ of yeast extract, $0.1 \mathrm{~g}$ of $\mathrm{KH}_{2} \mathrm{PO}_{4}, 0.1 \mathrm{~g}$ of $\left(\mathrm{NH}_{4}\right)_{2} \mathrm{SO}_{4}$, and $0.1 \mathrm{~g}$ of $\mathrm{MgSO}_{4} \cdot 7 \mathrm{H}_{2} \mathrm{O}$. In carbon source utilization tests, the optical density at $660 \mathrm{~nm}$ of a culture after cultivation in each medium was compared with the optical density of a culture grown in basal medium.

Quinone, fatty acid, and cell wall analyses. Quinones were extracted from fresh cells with chloroform-methanol $(2: 1, \mathrm{vol} / \mathrm{vol})$, purified by column chromatography, and analyzed by reverse-phase high-performance liquid chromatography (HPLC) (31). Whole-cell fatty acids were extracted as methyl ester derivatives with anhydrous methanolic $\mathrm{HCl}$ and then with $n$-hexane (13) and were analyzed by using a gas-liquid chromatograph equipped with a flame ionization detector (model HP5890; Hewlett-Packard). A gas-liquid chromatography-mass spectrometry analysis was performed with a model HP5970 mass selective detector directly connected to a gas-liquid chromatograph. The diamino acid in the cell wall peptidoglycan was determined by hydrolyzing cells with $6 \mathrm{~N} \mathrm{HCl}$ at $100^{\circ} \mathrm{C}$ for $18 \mathrm{~h}$ and then performing thin-layer chromatography (14). Mycolic acid methyl esters were determined by thin-layer chromatography after cells were hydrolyzed with $10 \% \mathrm{KOH}$-methanol and methylated with benzene-methanol- $\mathrm{H}_{2} \mathrm{SO}_{4}(10: 20: 1, \mathrm{vol} / \mathrm{vol} / \mathrm{vol})(14)$.

DNA base composition. DNA was purified by the method of Tamaoka and Komagata (32), as modified by Kamagata and Mikami (12). The guanine-pluscytosine $(\mathrm{G}+\mathrm{C})$ content of DNA was determined by performing HPLC with nuclease P1 hydrolysates of the DNA (12) by using a Yamasa GC kit (Yamasa Shoyu Co., Chosi, Japan).

16S ribosomal DNA sequencing and phylogenetic analysis. 16S ribosomal DNA fragments that corresponded to positions 8 to 1510 of Escherichia coli $16 \mathrm{~S}$ rRNA (2) were amplified by PCR from protease-digested cell lysates and were purified by agarose gel electrophoresis with resin binding. PCR-amplified $16 \mathrm{~S}$ ribosomal DNA was sequenced by the linear PCR sequencing method modified for automated fluorescence detection, and the reaction products were analyzed with a Pharmacia laser fluorescent DNA sequencer. Information concerning the PCR and DNA sequencing procedures used has been published previously (10, 11). Sequences were compiled from overlapping sequence data, and binary sequence similarity values were calculated with the DNASIS-MAC computer program (Hitachi Soft-ware Engineering, Co., Ltd., Tokyo, Japan). Multiple alignments of the sequences were performed, nucleotide substitution rates (13) were calculated, and a neighbor-joining phylogenetic tree (24) was reconstructed by using the CLUSTAL V program (7). Alignment gaps and unidentified base positions were not taken into consideration for the calculations.

Nucleotide sequence accession numbers. The sequence of strain $\mathrm{Y}-104^{\mathrm{T}}$ ( $\mathrm{T}=$ type strain) determined in this study has been deposited in the DDBJ, GSDB, EMBL, and NCBI nucleotide sequence databases under accession number D50066. The accession numbers for the sequences used as reference sequences are as follows: Actinoplanes utahensis, X80823; Aeromicrobium erythreum, M37200; Arthrobacter globiformis, M23411; Aureobacterium testaceum, X77445; Bacillus subtilis, X60646; Brevibacterium linens, X77451; Clavibacter michiganensis, X77435; Corynebacterium glutamicum, Z46753; Corynebacterium xerosis, M59058; Dermatophilus congolensis, M59057; Frankia sp., M55343; Kibdelosporangium aridum, X53193; Micrococcus luteus, M38242; Microlunatus phosphovorus, D26169; Mycobacterium phlei, M29566; Nocardia asteroides, X57949; Nocardioides jensenii, X53214; Propionibacterium theonii, X53220; Rhodococcus rhodochrous, X79288; Saccharothrix australiensis, X53193; and Streptomyces coelicolor, Y00411.

\section{RESULTS}

Isolation. Respiratory quinone profiles of activated sludge provide valuable information on the bacterial population structure of the sludge $(8,9)$. Thus, we assessed the predominant bacteria in sugar waste activated sludge by performing a quinone profile analysis before isolation. Our direct quinone profile analysis of the sludge revealed that menaquinones ac-

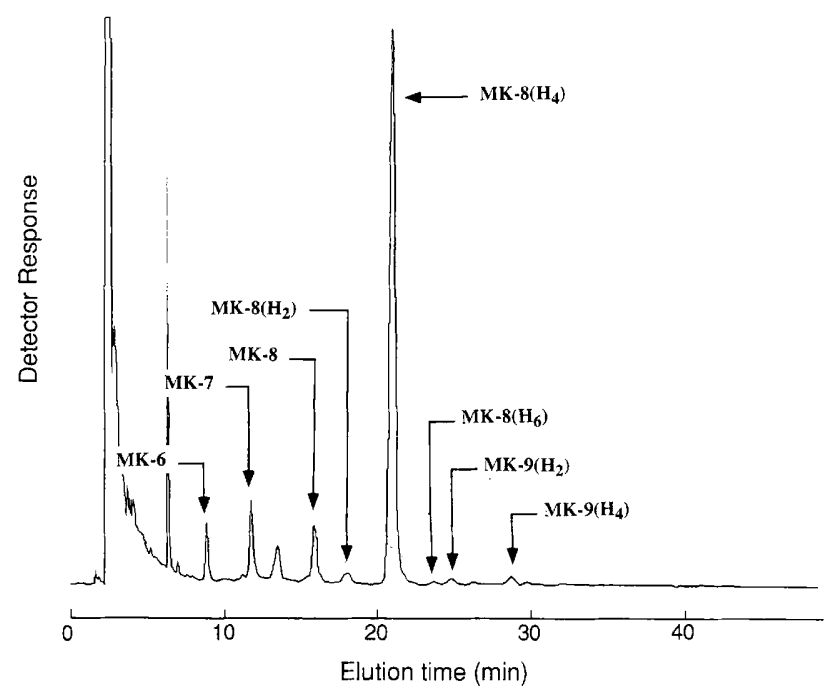

FIG. 1. HPLC profile of menaquinones isolated from activated sludge acclimated with synthetic wastewater containing glucose.

counted for more than one-half of the total quinone content of the sludge and that $\mathrm{MK}-8\left(\mathrm{H}_{4}\right)$ was the predominant menaquinone (Fig. 1). Also, microscopic studies showed that the sludge contained large numbers of well-compacted flocs consisting of large coccus-shaped bacteria. These results suggested that MK-8( $\left.\mathrm{H}_{4}\right)$-containing coccus-shaped bacteria predominated in the sludge tested.

Indeed, we isolated large numbers of coccus-shaped bacteria by the plate count method when we prolonged the incubation time for recovery to 2 weeks or more. Since the isolates which we obtained were phenotypically very similar, we selected one of these isolates and designated it strain $\mathrm{Y}-104^{\mathrm{T}}$ for taxonomic studies. Strain $\mathrm{Y}-104^{\mathrm{T}}$ produced menaquinones, and MK-8 $\left(\mathrm{H}_{4}\right)$ was the major homolog, as described below; this strain was considered one of the bacteria that predominated in the sludge which we studied.

Morphological characteristics. Strain Y $-104^{\mathbf{T}}$ was a grampositive, nonmotile, non-spore-forming, coccus-shaped bacterium. The cells were 0.8 to $3.0 \mu \mathrm{m}$ in diameter and occurred singly, in pairs, or in small irregular clusters (Fig. 2). Rodshaped or filamentous cells were not observed at any stage of growth. The cell size depended on the growth stage; large cells (more than $2.0 \mu \mathrm{m}$ in diameter) predominated at the early stage of the logarithmic growth phase, and the proportion of small cells increased during the late stage of the logarithmic growth phase (Fig. 3). The type of cell division was characteristic. Thin-section electron microscopy revealed that a cell wall-like structure occurred in the middle of each cell at the early growth phase (Fig. 4). Many septa were observed in the cells during the late logarithmic growth phase (Fig. 4).

Cultural characteristics. Strain Y $-104^{\mathrm{T}}$ exhibited low growth rates under all of the growth conditions which we used, even optimal growth conditions. The doubling time of this strain was about $11 \mathrm{~h}$ in a liquid medium at $\mathrm{pH} 7.0$ and $25^{\circ} \mathrm{C}$. Visible colonies appeared on agar media after 10 days of incubation. The colonies were circular, smooth, convex, and white at the early stage of growth. After about 2 weeks of incubation the colonies became cream colored.

Sugar uptake activity. The capacity for sugar uptake was one of the characteristic features of strain $\mathrm{Y}-104^{\mathrm{T}}$. This isolate took up all of the sugars supplied except xylose and accumulated large amounts of polysaccharide in its cells in the absence of 

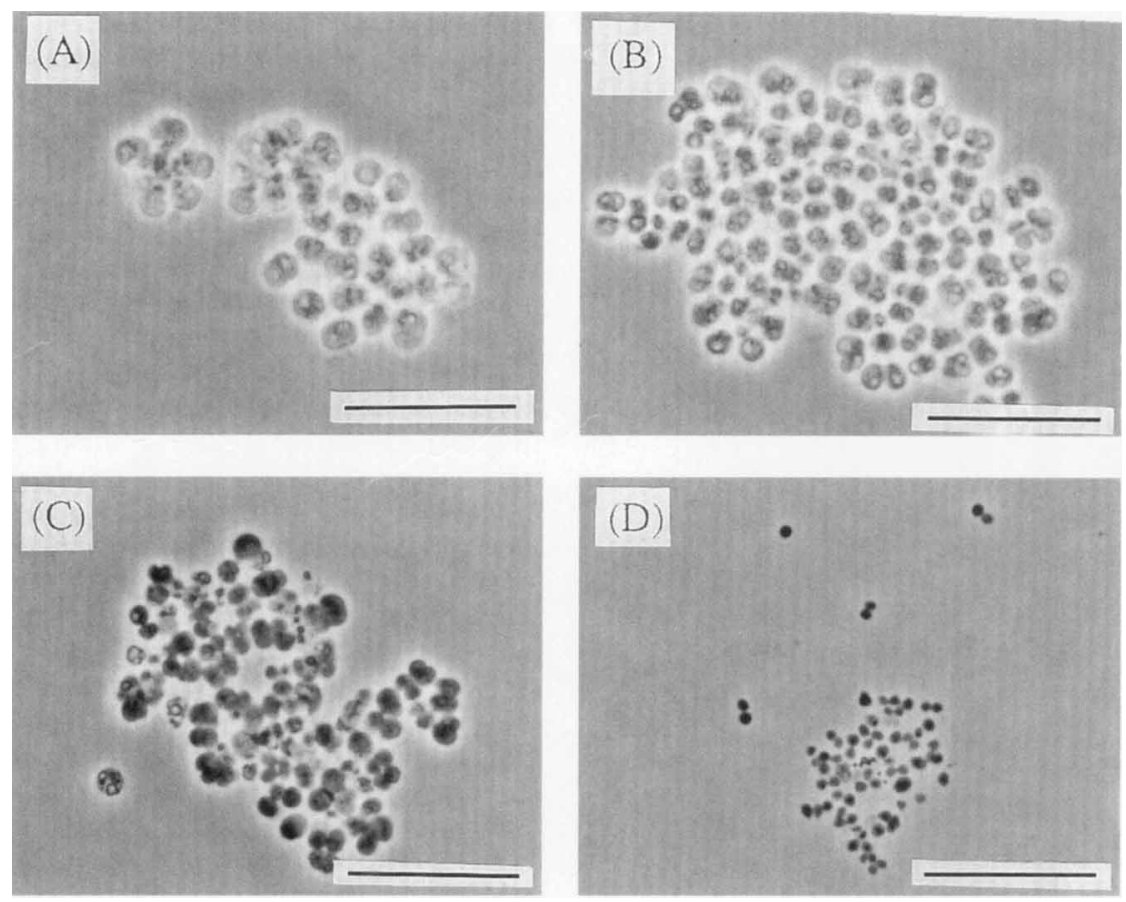

FIG. 2. Phase-contrast photomicrographs of strain Y-104 . Cells were harvested at the early growth phase (A), at the mid-logarithmic phase (B), at the late logarithmic phase (C), and at the stationary phase (D). Bars $=10 \mu \mathrm{m}$.

nitrogen and phosphate sources. Figure 5 shows glucose uptake by strain $\mathrm{Y}-104^{\mathrm{T}}$ under aerobic conditions. A culture containing $1 \mathrm{~g}$ of strain $\mathrm{Y}-104^{\mathrm{T}}$ per liter took up $1 \mathrm{~g}$ of glucose per liter almost completely in $1 \mathrm{~h}$. The polysaccharide content of the cells was about $50 \%$ (wt/wt, dry cells) after $1 \mathrm{~h}$ of incubation.

Physiological and biochemical characteristics. Strain Y-104 ${ }^{T}$ was an obligately aerobic chemoorganotroph that had a strictly respiratory type of metabolism with oxygen as the terminal electron acceptor. It could not grow under strictly anaerobic conditions. The temperature range for growth was 10 to $35^{\circ} \mathrm{C}$, and the optimum temperature was $25^{\circ} \mathrm{C}$. The $\mathrm{pH}$ range for growth was 5.0 to 9.0 , and maximum growth occurred at $\mathrm{pH}$ 7.0. Strain $\mathrm{Y}-104^{\mathrm{T}}$ was nonhalophilic, but was able to grow in the presence of $\mathrm{NaCl}$ concentrations of up to $6 \%$; no growth occurred in the presence of $\mathrm{NaCl}$ concentrations of $7 \%$ or more. Catalase was produced. Oxidase activity was negative. A wide variety of organic compounds were used as carbon and energy sources for growth. Good carbon sources were sugars and alcohols, including glucose, fructose, mannose, galactose, xylose, sucrose, maltose, lactose, mannitol, sorbitol, ethanol, propanol, glycerol, and starch. Pyruvate, aranine, glutamate, glutamine, and histidine were also utilized. Not utilized were acetate, malate, succinate, arginine, asparagine, methanol, and glycogen.

Chemotaxonomic characteristics and DNA base composition. HPLC experiments showed that strain $\mathrm{Y}-104^{\mathrm{T}}$ contained a menaquinone with eight tetrahydrogenated isoprene units [MK-8( $\left.\left(\mathrm{H}_{4}\right)\right]$ as its major quinone component $(97.0 \%)$. MK-7 $\left(\mathrm{H}_{4}\right)$, MK-8 $\left(\mathrm{H}_{2}\right)$, and MK-9 $\left(\mathrm{H}_{4}\right)$ were minor components. Gas chromatography of the fatty acid methyl ester derivatives from strain $\mathrm{Y}-104^{\mathrm{t}}$ revealed that the major components were iso$\mathrm{C}_{16: 0}(19.7 \%)$, iso- $C_{15: 0}(15.7 \%)$, and $C_{18: 1}(14.0 \%)$. Smaller but substantial amounts of $\mathrm{C}_{16: 0}(10.3 \%)$, anteiso- $\mathrm{C}_{15: 0}(9.2 \%)$, iso- $\mathrm{C}_{17: 0}(8.5 \%)$, and anteiso- $\mathrm{C}_{17: 0}(5.2 \%)$ were also found.
The cell wall peptidoglycan contained meso-diaminopimelic acid. Mycolic acids were not present.

The genomic DNA G $+\mathrm{C}$ content of strain $\mathrm{Y}-104^{\mathrm{T}}$ was 67.5 $\mathrm{mol} \%$, indicating that this strain belongs to the high- $\mathrm{G}+\mathrm{C}$ content group of gram-positive bacteria.
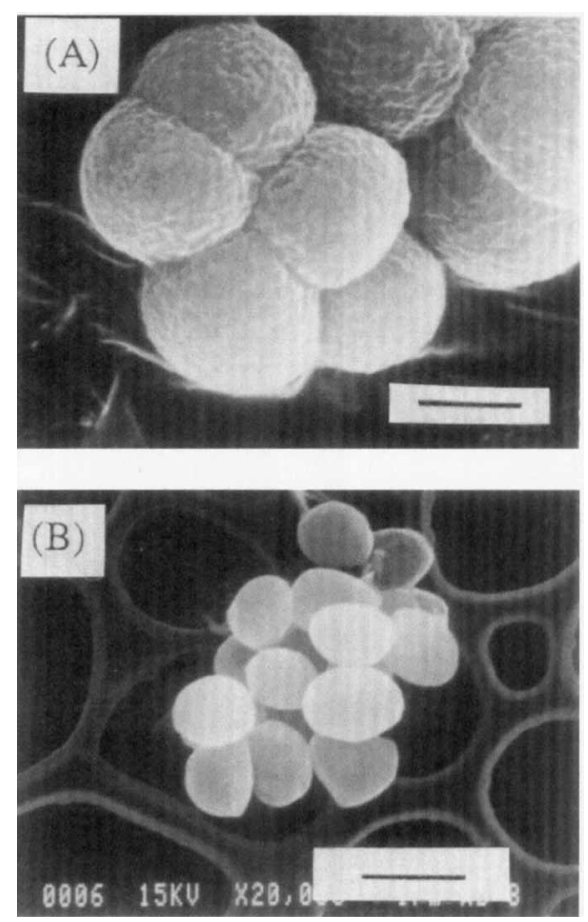

FIG. 3. Scanning electron micrographs of strain $\mathrm{Y}-104^{\mathrm{T}}$. Cells were harvested at the logarithmic phase $(A)$ and at the stationary phase $(B)$. Bars $=1 \mu \mathrm{m}$. 

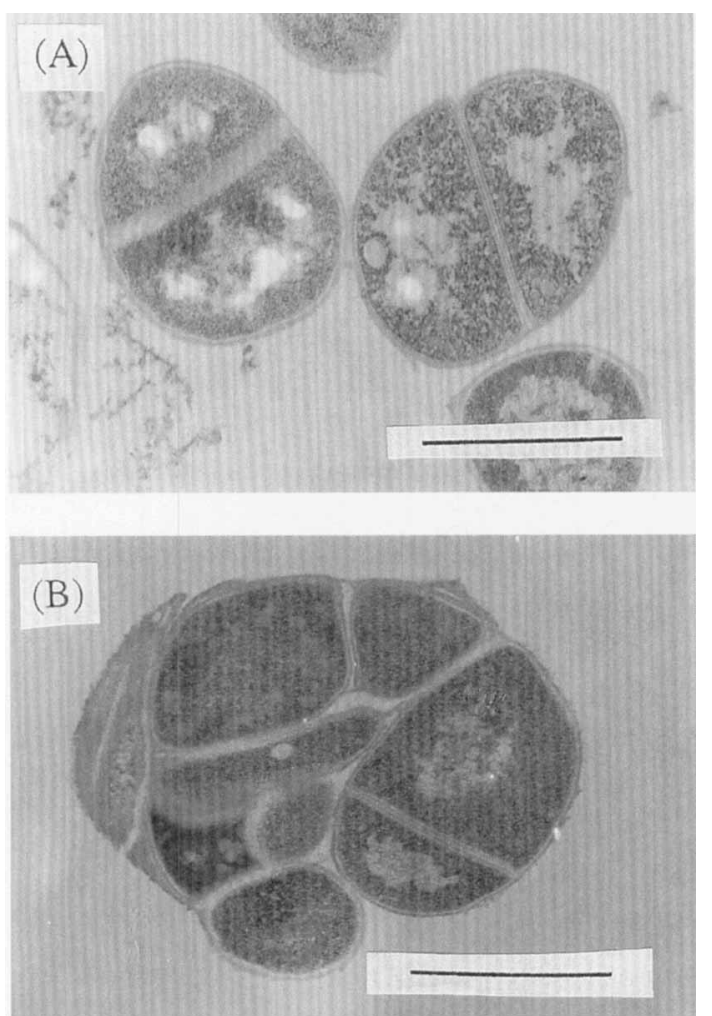

FIG. 4. Transmission electron micrographs of thin sections of strain Y-104 ${ }^{\mathrm{T}}$. Cells were harvested at the early growth phase (A) and at the late logarithmic phase (B). Bars $=1 \mu \mathrm{m}$.

Phylogenetic analysis. The 16S rRNA gene from the crude lysate of strain Y-104 ${ }^{\mathrm{T}}$ was amplified successfully by PCR and was sequenced directly by the linear PCR sequencing method, followed by automated fluorescence detection. The fragment whose sequence we determined was a continuous stretch of 1,290 residues (positions 28 to 1317), which accounted for $86 \%$ of the entire $16 \mathrm{~S}$ rRNA gene. The sequence determined in this study was compared with a data set consisting of 20 reference sequences for gram-positive species, and levels of binary sequence similarity and evolutionary distances were calculated (Table 1). Figure 6 shows a neighbor-joining phylogenetic tree that was reconstructed on the basis of the evolutionary distances calculated by using the 1,114 positions that could be aligned. The new isolate formed a lineage that was distinct from all members of the gram-positive genera compared; Frankia sp. was the closest phylogenetic neighbor.

\section{DISCUSSION}

As reported above, we successfully isolated and characterized polysaccharide-accumulating, coccus-shaped bacteria that were the predominant bacteria in activated sludge cultured under conditions in which glucose was added intermittently. Although these bacteria could not grow fast in synthetic media, they showed rapid substrate uptake and accumulation capacities in the absence of nitrogen and phosphate sources. The ability to take up and accumulate substrate may play an important role in the competition among various bacteria to take up limiting substrates in activated sludge processes. Because of morphological, physiological, and ecological similarities, these isolates may be identical to or taxonomically related to the gram-positive cocci described previously as the predominant bacteria in sugar waste activated sludge $(28,29)$. One of the new isolates, strain $\mathrm{Y}-104^{\mathrm{T}}$, is a gram-positive, non-spore-forming, nonmotile, coccus-shaped, strictly aerobic chemoorganotroph. This bacterium is also characterized chemotaxonomically by containing MK- $8\left(\mathrm{H}_{4}\right)$ as its major quinone, iso- $\mathrm{C}_{16: 0}$, iso- $\mathrm{C}_{15: 0}$, and $\mathrm{C}_{18: 1}$ as its major fatty acid components, and meso-diaminopimelic acid in its cell wall and by lacking mycolic acids. The $\mathrm{G}+\mathrm{C}$ content of the DNA of strain $\mathrm{Y}-104^{\mathrm{T}}$ is 67.5 mol\%, indicating that this bacterium belongs to the high$\mathrm{G}+\mathrm{C}$-content group of gram-positive bacteria.

In view of its cell morphology and ultrastructure, as well as its chemotaxonomic characteristics, strain $\mathrm{Y}-104^{\mathrm{T}}$ occupies a peculiar taxonomic position among the gram-positive cocci that belong to the high-G+C-content group. This isolate seems to be morphologically most similar to species belonging to the genera Luteococcus and Microlunatus but differs from these bacteria by having many septa in its cells at the stationary growth stage and by containing $\mathrm{MK}-8\left(\mathrm{H}_{4}\right)$ as its major quinone and meso-diaminopimelic acid in its cell wall. There are also marked chemotaxonomic differences between the new isolate and other previously described members of the high-G $+\mathrm{C}$ content gram-positive coccus group, including members of the genera Kineococcus (35), Micrococcus (25), Pelczaria (23), and Stomatococcus (1) (Table 2). Two gram-positive genera which contain MK-8 $\left(\mathrm{H}_{4}\right)$ and meso-diaminopimelic acid have been described previously: the genera Nocardia (16) and Dermatophilus (26). However, these genera are differentiated from our isolate by their hypha cell morphology. Members of the genus Rhodococcus often have a coccoid stage and contain mesodiaminopimelic acid (5). However, our isolate can be differentiated from Rhodococcus strains by its lack of mycolic acids.

Our phylogenetic analysis based on 16S rRNA gene sequence information demonstrated that strain $\mathrm{Y}-104^{\mathrm{T}}$ represents a line of descent which is distinct from the previously described genera of gram-positive bacteria and that the genus Frankia is the nearest phylogenetic neighbor. Since members of the genus Frankia (18) are hypha shaped and have partially hydrogenated menaquinones with nine isoprene units as their major quinones, it is easy to differentiate our isolate from these bacteria. However, it is interesting that the "conidium" (or "vasicle") formed by members of the genus Frankia is similar to the cells of our strain morphologically. The levels of binary sequence similarity between strain $\mathrm{Y}-104^{\mathrm{T}}$ and Frankia sp. or

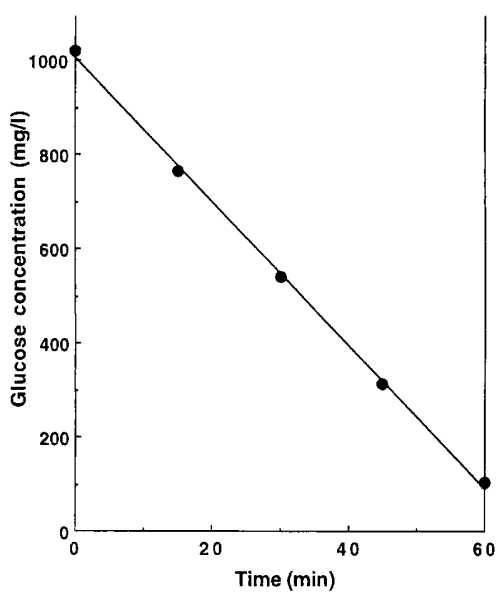

FIG. 5. Glucose uptake by strain Y-104 ${ }^{\mathrm{T}}$. Strain $\mathrm{Y}-104^{\mathrm{T}}$ was harvested the early stationary phase, washed, and suspended in distilled water at a concentration of $1,000 \mathrm{mg}$ (dry weight) of cells per liter. Glucose was added to the suspension, and then the preparation was incubated aerobically at $25^{\circ} \mathrm{C}$. 


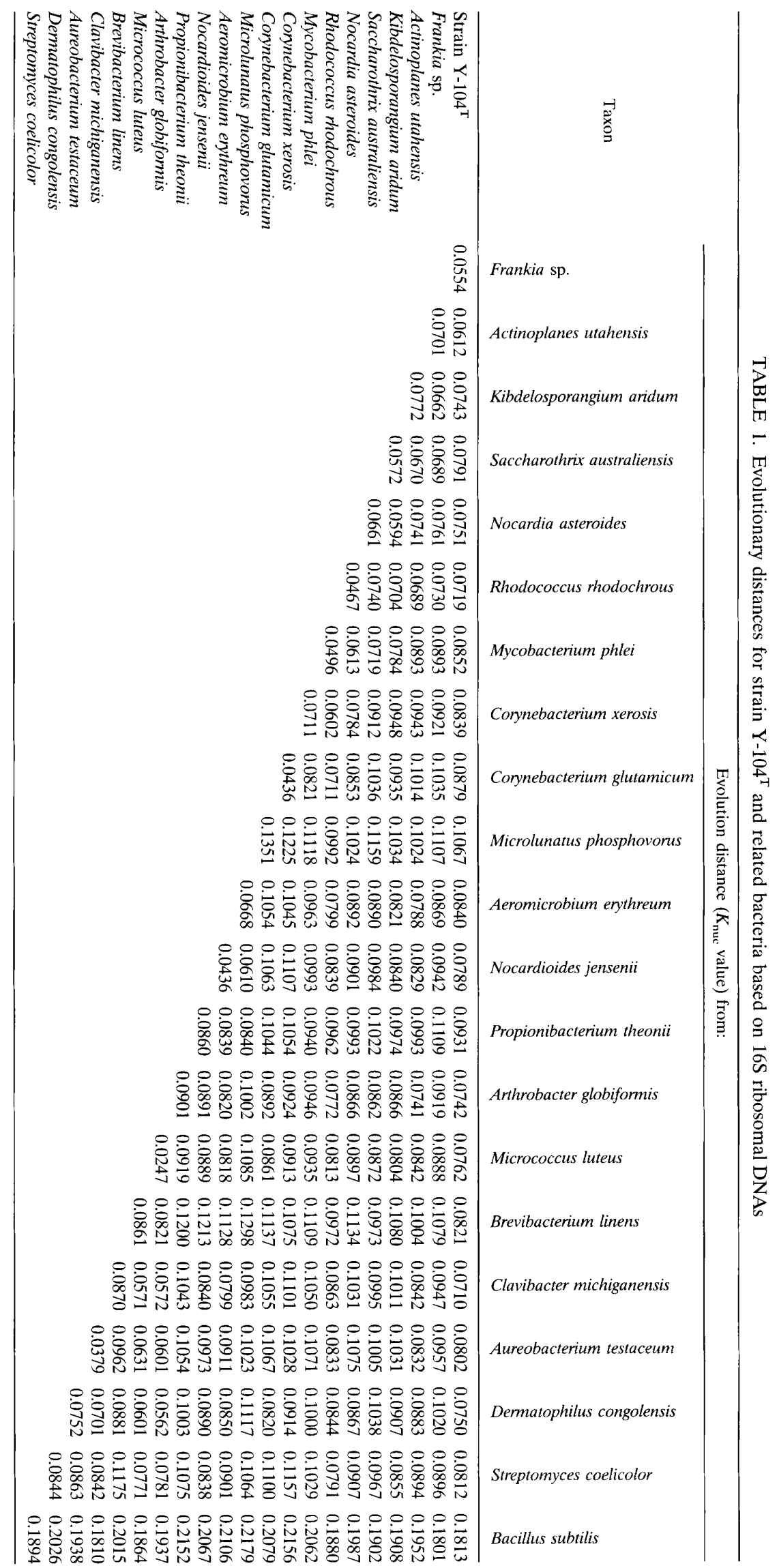




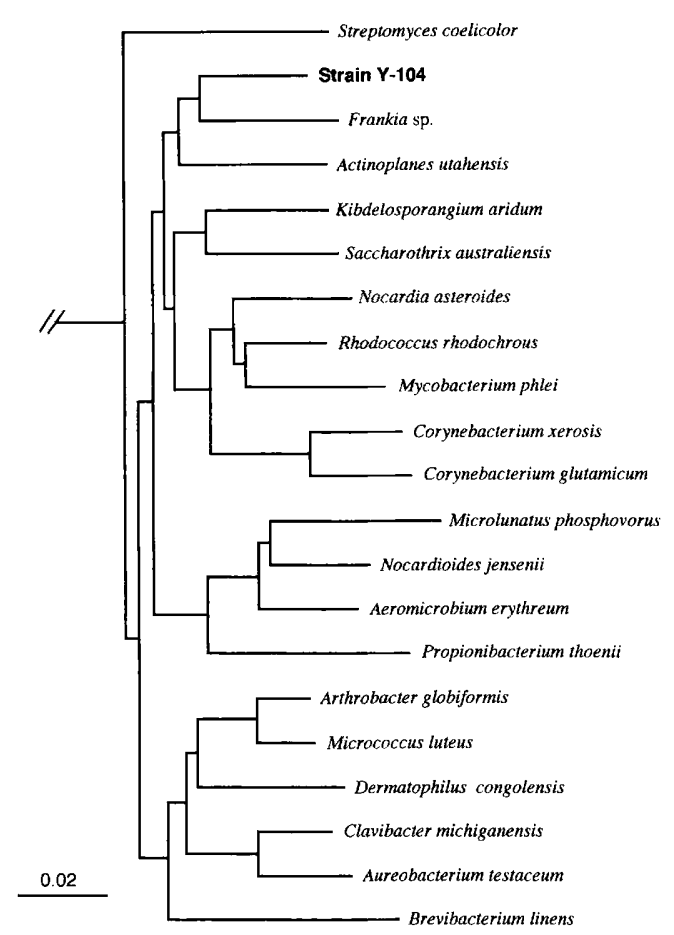

FIG. 6. Distance matrix tree showing phylogenetic relationships among strain $\mathrm{Y}-104^{\mathrm{T}}$ and related bacteria belonging to the high- $\mathrm{G}+\mathrm{C}$-content grampositive group. The sequence of Bacillus subtilis was used to root the tree. Bar = $0.02 K_{\text {nuc }}$

related species having high DNA $\mathrm{G}+\mathrm{C}$ contents are less than $93 \%$, and this value seems to be low enough to justify classification of the new isolate in a new genus.

Although only one isolate, strain $\mathrm{Y}-104^{\mathrm{T}}$, was characterized in this study, the ecological importance of this bacterium in sugar waste activated sludge, together with our phenotypic, chemotaxonomic, and phylogenetic data, warrant creation of a new genus and species for this isolate. Thus, we propose the name Microsphaera multipartita gen. nov., sp nov. for strain $\mathrm{Y}-104^{\mathrm{T}}$. Descriptions of the new genus and species are given below.

Description of Microsphaera gen. nov. Microsphaera (Mi.cro. sphae'ra. Gr. adj. micros, small; M. L. fem. n. sphaera, sphere; M. L. fem. n. Microsphaera, small coccoid microorganism). Cells are spherical (diameter, 0.8 to $3.0 \mu \mathrm{m}$ ) and occur singly or in some cases in clusters. A cell wall structure occurs in the middle of each cell at the early logarithmic growth phase, and a number of septa are present at the late logarithmic phase. Nonmotile. Spores are not formed. Gram positive. Aerobic chemoorganotroph, having a strictly respiratory type of metabolism with oxygen as the terminal electron acceptor. The growth rate is low. Visible colonies appear on agar media after 10 days of incubation. Catalase positive. Oxidase negative. The cell wall peptidoglycan contains meso-diaminopimelic acid. The major quinone is MK- $8\left(\mathrm{H}_{4}\right)$. The major fatty acids are iso- $\mathrm{C}_{16: 0}$, iso- $C_{15: 0}$, and $C_{18: 1}$. The $\mathrm{G}+\mathrm{C}$ content of the DNA is 67.5 mol\%. The phylogenetic position is in the high-G+C-content group of gram-positive bacteria; the genus Frankia is the closest relative.

The type species is Microsphaera multipartita.

Description of Microsphaera multipartita sp. nov. Microsphaera multipartita (mul.ti.par.ti'ta. M. L. adj. multus, many; M. L. v. partitre, divide; M. L. fem. part. pass. multipartita, microorganism having many divisions inside the cell). The morphology of this species and its chemotaxonomic characteristics are the same as those described above for the genus. The colonies are circular, smooth, convex, and white at the early stage of growth. After about 2 weeks of incubation the colonies are cream colored. The optimum growth temperature is $25^{\circ} \mathrm{C}$. The optimum $\mathrm{pH}$ is 7.0. No growth occurs in the presence of an $\mathrm{NaCl}$ concentration of $7 \%$ or more. The doubling time is about $11 \mathrm{~h}$ in liquid medium. The polysaccharide content of the cells may be high (sometimes more than $50 \%$ [wt/wt] depending on the culture conditions). Catalase positive. Oxidase negative. Good carbon sources are sugars and alcohols and include D-xylose, D-glucose, D-fructose, D-mannose, D-galactose, sucrose, maltose, lactose, mannitol, sorbitol, glycerol, ethanol, and propanol. Starch, pyruvate, alanine, glutamate, glutamine, and histidine

TABLE 2. Differential characteristics of Microsphaera gen. nov. and related genera belonging to the gram-positive high-G+C-content group ${ }^{a}$

\begin{tabular}{|c|c|c|c|c|c|c|}
\hline Genus & $\begin{array}{c}\text { Cell } \\
\text { morphology }\end{array}$ & $\begin{array}{l}\text { Growth response } \\
\text { to oxygen }\end{array}$ & $\begin{array}{l}\text { Diamino } \\
\text { acid }\end{array}$ & Menaquinone(s) & Cellular fatty acid(s) & $\begin{array}{l}\mathrm{G}+\mathrm{C} \text { content } \\
\quad(\mathrm{mol} \%)\end{array}$ \\
\hline Microsphaera & Coccus & a & meso-DAP & MK- $8\left(\mathrm{H}_{4}\right)$ & iso- $\mathrm{C}_{15: 0}$, iso- $\mathrm{C}_{16: 0}, \mathrm{C}_{18: 1}$ & 67.5 \\
\hline Frankia $^{b}$ & Hypha & a & meso-DAP & MK-9 $\left(\mathrm{H}_{4}\right),\left(\mathrm{H}_{6}\right),\left(\mathrm{H}_{8}\right)$ & $\mathrm{C}_{15: 0}$, iso- $\mathrm{C}_{16: 0}, \mathrm{C}_{17: 1}$ & $66-71$ \\
\hline Nocardia $^{c}$ & Hypha & a & meso-DAP & MK-8 $\left(\mathrm{H}_{4}\right)$, MK-9 $\left(\mathrm{H}_{2}\right)$ & $\mathrm{C}_{16: 0}, \mathrm{C}_{18: 1}, 10 \mathrm{Me} 19$ & $64-72$ \\
\hline Dermatophilus $^{d}$ & Hypha & a & meso-DAP & MK-8( $\left(\mathrm{H}_{4}\right)$ & $\mathrm{C}_{14: 0}, \mathrm{C}_{16: 0}, \mathrm{C}_{17: 0}$ & $57-59$ \\
\hline Kineococcus $^{e}$ & Coccus & a & meso-DAP & MK-9( $\left.\mathrm{H}_{2}\right)$ & anteiso-C $\mathrm{C}_{150}$ & 73.9 \\
\hline Luteococcus $^{\prime}$ & Coccus & $\mathrm{f}$ & LL-DAP & MK-9 $\left(\mathrm{H}_{4}\right)$ & $\mathrm{C}_{16: 1}, \mathrm{C}_{17: 1}, \mathrm{C}_{18: 1}$ & $66-68$ \\
\hline Microlunatus ${ }^{g}$ & Coccus & a & LL-DAP & MK-9 $\left(\mathrm{H}_{4}\right)$ & anteiso- $\mathrm{C}_{15: 0}$, iso- $\mathrm{C}_{15: 0}$, iso- $\mathrm{C}_{16: 0}$ & 67.9 \\
\hline Micrococcus $^{h}$ & Coccus & a & L-Lys & $\begin{array}{l}\left.\text { MK-8( } \mathrm{H}_{2}\right), \text { MK-9 }\left(\mathrm{H}_{2}\right) \\
\text { MK-7, MK-8, MK-7 }\left(\mathrm{H}_{2}\right)\end{array}$ & anteiso- $\mathrm{C}_{15: 0}$ & $65-75$ \\
\hline Stomatococcus ${ }^{i}$ & Coccus & $\mathrm{f}$ & L-Lys & ND & anteiso- $\mathrm{C}_{15 \cdot 0}$, iso- $\mathrm{C}_{16 \cdot 0}$ & $56-60$ \\
\hline Pelczariai & Coccus & a & L-Lys & ND & ND & 59.0 \\
\hline
\end{tabular}

${ }^{a}$ Abbreviations: a, aerobe; f, facultative anaerobe; meso-DAP, meso-diaminopimelic acid; LL-DAP, LL-diaminopimelic acid; L-Lys, L-lysine; ND, not determined; $10 \mathrm{Me} 19,10$-methylnonacosanoic acid; iso, iso branched; anteiso, anteiso branched.

${ }^{b}$ Data from references 18 and 19

${ }^{c}$ Data from references $3,4,15$, and 16 .

${ }^{d}$ Data from references 17 and 26.

e Data from reference 35.

${ }^{f}$ Data from reference 33

${ }^{g}$ Data from reference 21

${ }^{h}$ Data from reference 25

${ }^{i}$ Data from reference 1.

${ }^{j}$ Data from reference 23. 
are also utilized. Not utilized are glycogen, methanol, acetate, malate, succinate, arginine, and asparagine.

Occurs in activated sludge cultured in fed-batch reactors under aerobic conditions.

The type strain is strain Y-104, which has been deposited in the Japan Collection of Microorganisms (RIKEN) as strain JCM 9543.

\section{ACKNOWLEDGMENTS}

We thank Yoshikuni Urushigawa, National Institute for Resources and Environment, Agency of Industrial Science and Technology, for help with the fatty acid analysis, Mayumi Erata for help with electron microscopy, and Yoichi Kamagata and Mamoru Kawaharasaki, National Institute of Bioscience and Human-Technology, Agency of Industrial Science and Technology, for advice concerning experiments.

\section{REFERENCES}

1. Bergan, T., and M. Kocur. 1982. Stomatococcus mucilaginosus gen. nov., sp. rev., a member of the family Micrococcaceae. Int. J. Syst. Bacteriol. 32: 374-377.

2. Brosius, J., J. L. Palmer, J. P. Kennedy, and H. F. Noller. 1978. Complete nucleotide sequence of a $16 \mathrm{~S}$ ribosomal RNA gene from Escherichia coli. Proc. Natl. Acad. Sci. USA 75:4801-4805.

3. Collins, M. D., M. Goodfellow, D. E. Minnikin, and G. Alderson. 1985. Menaquinone composition of mycolic acid-containing actinomycetes and some sporoactinomycetes. J. Appl. Bacteriol. 58:77-86.

4. Collins, M. D., T. Pirouz, M. Goodfellow, and D. E. Minnikin. 1977. Distribution of menaquinones in actinomycetes and corynebacteria. J. Gen. Microbiol. 100:221-230.

5. Goodfellow, M., and G. Alderson. 1977. The actinomycete-genus Rhodococcus: a home for the 'rhodochrous' complex. J. Gen. Microbiol. 100:99-122.

6. Herbert, D., P. J. Phipps, and R. E. Strange. 1971. Chemical analysis of microbial cells. Methods Microbiol. 5b:265-278.

7. Higgines, D. G., A. J. Bleasby, and R. Fuchs. 1992. CLUSTAL V: improved software for multiple sequence alignment. Comput. Appl. Biosci. 8:189-191

8. Hiraishi, A. 1988. Respiratory quinone profiles as tools for identifying different bacterial populations in activated sludge. J. Gen. Appl. Microbiol. 34: $39-56$.

9. Hiraishi, A. 1989. Isoprenoid quinone profiles for identifying and classifying microorganisms in the environment, p. 663-668. In T. Hattori et al. (ed.), Recent advances in microbial ecology. Japan Scientific Societies Press, Tokyo.

10. Hiraishi, A. 1992. Direct automated sequencing of 16S rDNA amplified by polymerase chain reaction from bacterial cultures without DNA purification. Lett. Appl. Microbiol. 15:210-213.

11. Hiraishi, A., Y. K. Shin, Y. Ueda, and J. Sugiyama. 1994. Automated sequencing of PCR-amplified 16S rDNA on 'Hydrolink' gels. J. Microbiol. Methods 19:145-154.

12. Kamagata, Y., and E. Mikami. 1991. Isolation and characterization of a novel thermophilic Methanosaeta strain. Int. J. Syst. Bacteriol. 41:191-196.

13. Kimura, M. 1980. A simple method for estimating evolutionary rates of base substitution through comparative studies of nucleotide sequences. J. Mol. Evol. 16:111-120.

14. Komagata, K., and K. Suzuki. 1987. Lipid and cell-wall analysis in bacterial systematics. Methods Microbiol. 19:161-207.

15. Kudo, T., K. Hatai, and A. Seino. 1988. Nocardia seriolae sp. nov. causing nocardiosis of cultured fish. Int. J. Syst. Bacteriol. 38:173-178.

16. Lechevalier, H. A. 1986 . Nocardioforms, p. $1458-1465$. In P. H. A. Sneath, N. S. Mair, M. E. Sharpe, and J. G. Holt (ed.), Bergey's manual of systematic bacteriology, vol. 2. The Williams \& Wilkins Co., Baltimore.

17. Lechevalier, M. P. 1986. Actinomycetes with multilocular sporangia, p. 2409 2410. In P. H. A. Sneath, N. S. Mair, M. E. Sharpe, and J. G. Holt (ed.), Bergey's manual of systematic bacteriology, vol. 4 . The Williams \& Wilkins Co., Baltimore.

18. Lechevalier, M. P. 1994. Taxonomy of the genus Frankia (Actinomycetales). Int. J. Syst. Bacteriol. 44:1-8.

19. Mirza, M. S., J. D. Janse, D. Hahn, and A. D. L. Akkermans. 1991. Identification of a typical Frankia strain by fatty acid analysis. FEMS Microbiol. Lett. 83:91-98.

20. Nakamura, K., and M. Dazai. 1986. Growth characteristics of batch-cultured activated sludge and its phosphate elimination capacity. J. Ferment. Technol. 64:433-439.

21. Nakamura, K., A. Hiraishi, Y. Yoshimi, M. Kawaharasaki, K. Masuda, and Y. Kamagata. 1995. Microlunatus phosphovorus gen. nov., sp. nov., a new gram-positive polyphosphate-accumulating bacterium isolated from activated sludge. Int. J. Syst. Bacteriol. 45:17-22.

22. Nakamura, K., K. Masuda, and E. Mikami. 1991. Isolation of a new type of polyphosphate accumulating bacterium and its phosphate removal characteristics. J. Ferment. Bioeng. 71:258-263.

23. Poston, J. M. 1976. Pelczaria aurantia gen. nov., sp. nov., a newly described orange-colored bacterium. Arch. Microbiol, 160:114-120.

24. Saitou, N., and M. Nei. 1987. The neighbor-joining method: a new method for reconstructing phylogenetic trees. Mol. Biol. Evol. 4:406-425.

25. Schleifer, K. H. 1986. Gram-positive cocci, p. 999-1103. In P. H. A. Sneath, N. S. Mair, M. E. Sharpe, and J. G. Holt (ed.), Bergey's manual of systematic bacteriology, vol. 2. The Williams \& Wilkins Co., Baltimore.

26. Stackebrandt, E., R. M. Kroppenstedt, and V. J. Fowler. 1983. A phylogenetic analysis of family Dermatophilaceae. J. Gen. Microbiol. 129:1831-1838.

27. Takii, S. 1970. Accumulation of glycogen-like polysaccharide in glucoseacclimated activated sludge. J. Ferment. Technol. 48:350-360.

28. Takii, S. 1973. Accumulation of glycogen-like polyglucose in activated sludge-dominant species in glucose-acclimated activated sludge. J. Jpn. Biol. Soc. Water Waste 9:1-5.

29. Takii, S. 1977. Accumulation of reserve polysaccharide in activated sludge treating carbohydrate wastes. Water Res. 11:79-83.

30. Takii, S. 1977. Bacterial characteristics of activated sludge treating carbohydrate wastes. Water Res, 11:85-89.

31. Tamaoka, J., Y. Katayama-Fujimura, and H. Kuraishi. 1983. Analysis of bacterial menaquinone mixtures by high performance liquid chromatography. J. Appl. Bacteriol. 54:31-36.

32. Tamaoka, J., and K. Komagata. 1984. Determination of DNA base composition by reversed-phase high-performance liquid chromatography. FEMS Microbiol. Lett. 25:125-128.

33. Tamura, T., M. Takeuchi, and A. Yokota. 1994. Luteococcus japonicus gen. nov., sp. nov., a new gram-positive coccus with LL-diaminopimelic acid in the cell wall. Int. J. Syst. Bacteriol. 44:348-356.

34. van Gills, H. W. 1964. Bacteriology of activated sludge. Report no. 32. Research Institute of Public Health Engineering, The Netherlands.

35. Yokota, A., T. Tamura, T. Nishii, and T. Hasegawa. 1993. Kineococcus aurantiacus gen. nov., sp. nov., a new aerobic, gram-positive, motile coccus with meso-diaminopimelic acid and arabinogalactan in the cell wall. Int. J. Syst. Bacteriol. 43:52-57. 